\section{Research of bauxite deposits from underground mining works}

The Mining-Geology-Petroleum Engineering Bulletin UDC: 622.1:622.2

DOI: 10.17794/rgn.2018.3.10

Review scientific paper (c) (i)

\author{
Ivan Budeš'; Ivo Galić́; Ivan Dragičevićs \\ ${ }^{I}$ Rudnici boksita Jajce d.d. Jajce, Trg hrvatskih branitelja b.b. Jajce, B\&H \\ ${ }^{2}$ University of Zagreb, Mining, Geology and Petroleum Engineering Faculty, Pierottijeva 6, 10000 Zagreb \\ ${ }^{3}$ Zelinska 2, 10000 Zagreb
}

\begin{abstract}
This paper presents a new approach to exploring bauxite deposits from underground mining works in the bauxitebearing mines of Bešpelj near Jajce in Bosnia and Herzegovina. In the area under consideration, bauxite deposits have been investigated and exploited for over 60 years. Despite the high degree of exploration in the geologically complicated structures of Bešpelj, there are numerous unexplored reserves. Up to now, they have been mainly investigated by drilling from the surface into the borehole network as dictated by legal geological regulations. Due to the increase in depths on which deposits are located and complex structural relationships, such research has become more expensive and less effective. From a geological point of view, the bauxite deposits have developed in the horizontal position. However, longlasting geological evolution from the Upper Cretaceous to the present, has brought deposits in very different structural positions. That is why we find them in an inclined position, in subvertical and vertical, and often in an overturned position. For further research to become rational and efficient, a new approach of study from underground mining works was developed that will serve for study and then for the exploitation of bauxite deposits.
\end{abstract}

\title{
Keywords
}

Bauxite deposits, geological research, new approach, underground mining works.

\section{Introduction}

In the wider Bauxite area of Jajce, there are numerous high-quality bauxite deposits. There are four bauxitebearing sites: Crvene Stijene, Poljane, Bešpelj and Liskovica. Crvene Stijene and Poljane are areas which have mostly been studied from the surface, while the remaining deposits of bauxite are exploited by underground mining works. The bauxite-bearing areas of Bešpelj and Liskovica have not yet been sufficiently explored. However, according to well-known geological data, it is assumed that there are still undiscovered, very valuable deposits deep beneath the surface of the terrain in all the bauxite areas (Farkaš, 2006, Slanc, 2011). These facts further justify investment in research.

The area of Bešpelj is characterized by intricate structural geological relations. Numerous and diverse geological investigations have found deposits in inclined, vertical and inverse positions. They are located from the surface to a depth of several hundred meters. In addition to the deposits on the surface of the terrain that represent erosion residues, the rest have clearly defined stratigraphic underlying and overlying rocks. In inclined deposits, they are mining underlying and overlying rocks at the same time. In the overturned position, the stratigraphic underlying

Corresponding author: Ivo Galić

ivo.galic@oblak.rgn.hr rocks become mining overlying rocks and the stratigraphic overlying rocks become mining underlying deposits. In the primary, i.e. in the horizontal position, the bauxite deposits occupy a significant ground-plan, while in the case of the subvertical and vertical position of the deposits, this ground-plan has a very narrow elongated octagonal zone that closely follows the contact of the underlying and overlying rocks. Such a structural pattern has an important effect on the path of bauxite deposit studies. If we continue drilling research in the well-drilled well network from the ground surface, the probability of finding a deposit in this very narrow and steep zone is reduced to a minimum. Increasing depth further increases the quantum of research drilling works.

For this reason, a new rational approach to research involving a combination of underground mining rooms and exploration drills was proposed. It should be noted immediately that the underground mining rooms, after researching the deposits, are also used for the exploitation of bauxite.

\section{Natural characteristics of the bauxite- bearing Bešpelj area}

\subsection{Geographic position}

The bauxite area of Bešpelj is located about 10 kilometers north of Jajce and occupies an area of about 20 $\mathrm{km}^{2}$. The northern boundary of the area is Ugar Canyon. 
The eastern boundary of the area is Ober Mountain. The southern boundary is marked by the steep slopes of Studenac and Debeljak, and the western boundary is outlined by the Vrbas River canyon. Bešpelj represents a small plateau at an average altitude of about $900 \mathrm{~m}$
(Dragičević et al., 2003). On the plateau, there are two settlements: Donji and Gornji Bešpelj. A transport connection with Bešpelj has been achieved by an asphalt road from Jajce via Divičani and Kuprešani, at a length of $25 \mathrm{~km}$.

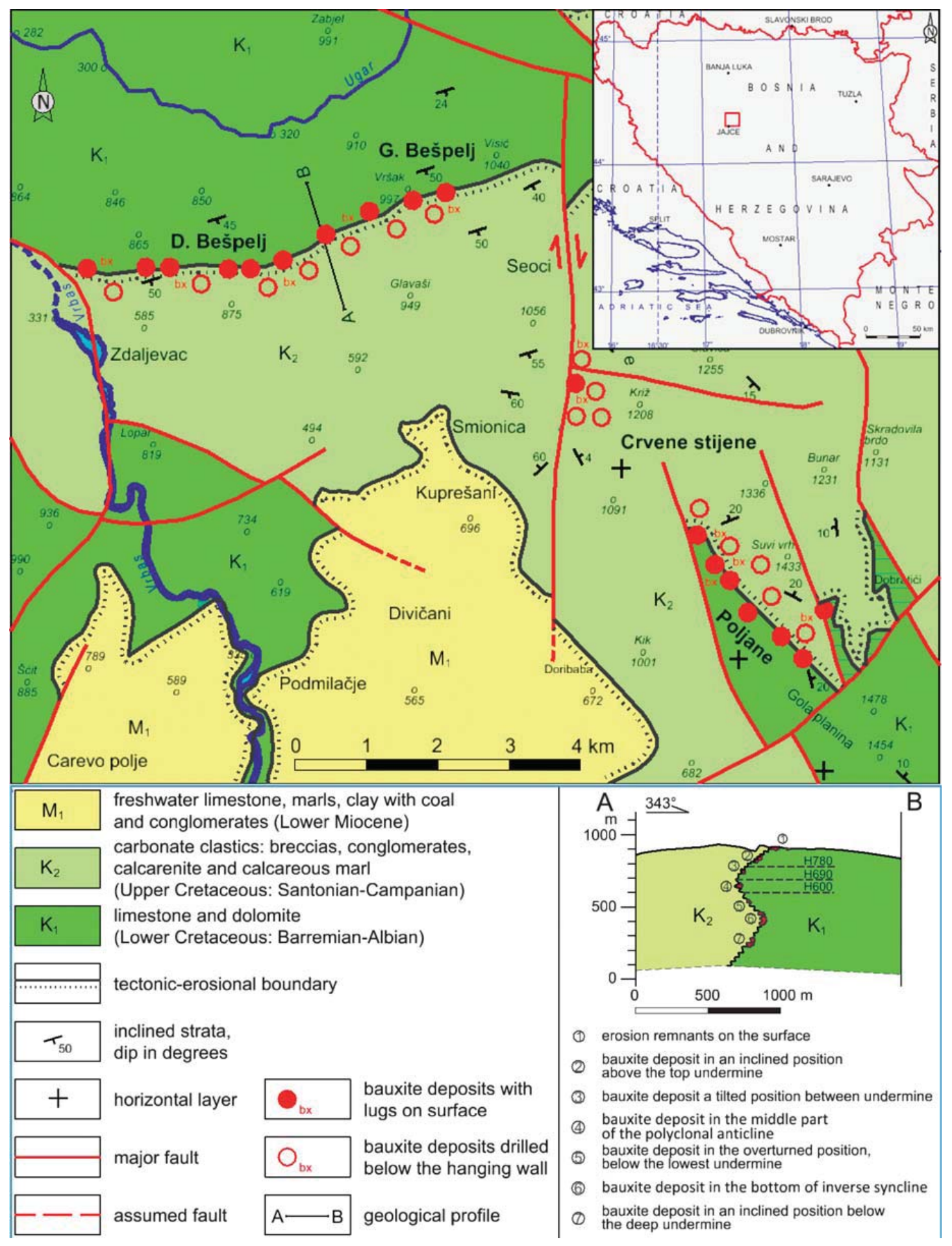

Figure 1: Geographical position and geological map of bauxite areas in Jajce (Marinković \& Ahac, 1975; supplemented and adapted to Dragičević, 1981, 1987, 1997) 


\subsection{Geological structure}

The geological structure of the broader bauxite area is shown in Figure 1. The fundamental geological relations are solved by the creation of a basic geological map, 1: 100,000, the Jajce sheet (Marinković and Ahac, 1975). According to this data, the bauxite deposits are related to a terrestrial phase, respectively the stratigraphic gap between the Cenoman-Turonian limestone in the foot wall and the Senonian carbonate sediments in the hanging wall of bauxite deposits. This is a tectonic-erosive discordance with an angle of discordance up to $10^{\circ}$.

Structural relations in the area are complicated. The main structural deformations are represented by folds and faults with a W-E strike. Most of the faults are of the reverse type. Folds are asymmetrical to overturned, with axial surfaces inclined to the south.

Due to very valuable bauxites, over the past 60 years, a wide variety of geological studies have been carried out in the Bešpelj area. More precisely, the stratigraphic position of the bauxite reservoir was defined, along with the duration of the stratigraphic gaps. It was found that the foot wall of the bauxite is a shallow marine limestone of late Albian age, and the hanging wall sediments are represented by heterogeneous carbonate clasts, sporadically limestones, of Campanian and Maastrichtian age (Dragičević, 1981, 1987, 1997). So the terrestrial phase during which bauxites were created lasted about 18 million years. The special value of these works are geological profiles which, very carefully and on the basis of the borehole data, give an exact picture of the complexity of the structural relations in the area of Bešpelj. The structural position of the base, respectively the contact surface of the foot wall-to-hanging wall is shown in detail. Some of the deposits are in a tilted position, most of them are very steep to vertical, and part of the deposits in the overturned position, which further complicates exploration and exploitation (Hajsek, 2005; Galić et al., 2006-1, 2006-2; Dragičević \& Velić, 2006; Budeš, 2009; Crnoja, 2015).

\subsection{The position of the bauxite deposits within geological strutures}

The primary, i.e. depositional position of all deposits is horizontal (see Figure 2a, horizontal). In general, if bauxites are in this position, they are not significantly affected by tectonic processes. There are no such bauxite deposits in the area of Bešepelj. The very common structural position of the bauxite deposits is that it is inclined together with the foot wall and hanging layers (Bárdossy, 2013). They are located in the area of Bešpelj near the tectonic and erosion boundaries (see Figure 2b, inclined). Further tilting of the contact surface between the foot wall and the hanging wall of the deposits, resulted in a very steep (subvertical) to vertical position of bauxite (see Figure 2c, vertical). Due to further tangential-compressive tectonic effects, the inverse position of the contact surface between the foot wall and the hanging wall layers was formed together with the bauxite deposits (see Figure 2d, overturned).

In cases where the deposits are in very steep, vertical and overturned positions, the study area becomes a very narrow zone extending to the surface along with the cartographic line of the transgressive boundary. It should be noted that in the overturned positions of the bauxite deposits, the stratigraphic underlying rocks (limestone) become mining overlying rocks, and the stratigraphic overlying rocks (mainly carbonate clast) become mining underlying rocks (Budeš, 2009; Crnoja, 2015). Such structural relations make it very difficult to study surface deposits, so such research is regularly economically unjustified. This is the reason why a new approach to study deposits from underground mining facilities was proposed.

\section{Study of the bauxite deposits from underground mining rooms}

The first ideas on the study of bauxite deposits from underground mining facilities in the area of Bešpelj were

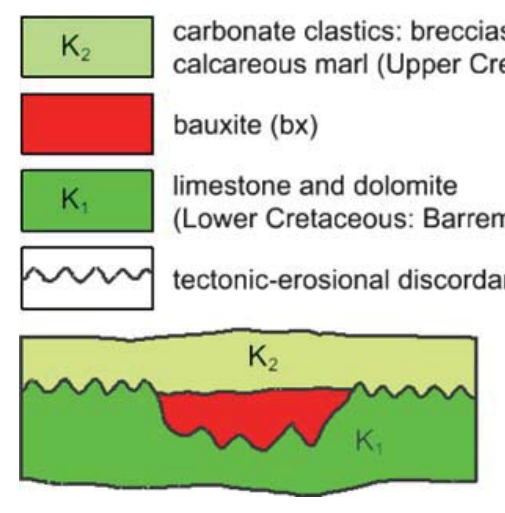

a) horizontal

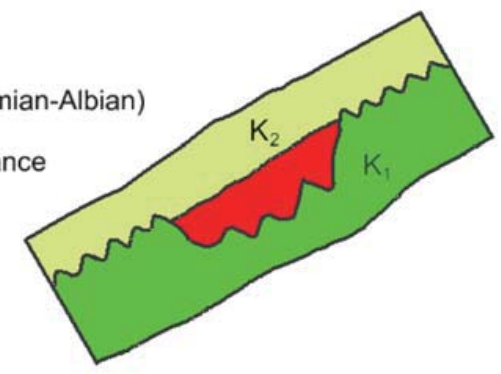

b) inclined

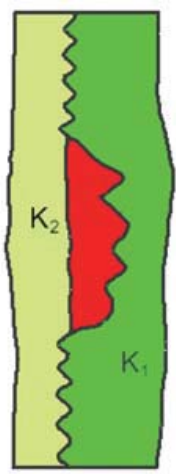

c) vertical

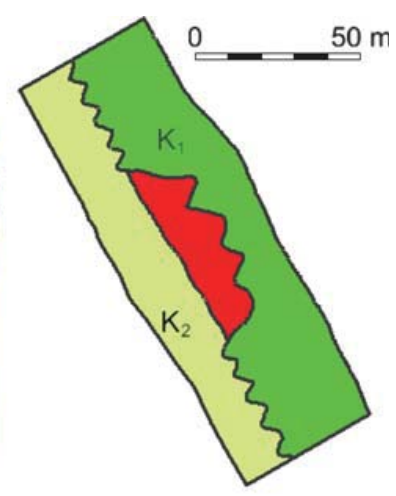

d) overturned

Figure 2: Schematic illustration of the structural position of the bauxite deposits (Budeš, 2009) 
given by Ilić (1989) in the conceptual solution for the study and opening of the Bešpelj deposits in the bauxite Jajce mine. The methodology was well established, but for unknowledges of stratigraphic and thus structural relations directly to the contact surface, the practical application of these methods did not yield the expected results. Namely, the location of the contact surface, which is only relevant for locating the base, is changed by stretching and tilting from inclined to steeply inclined, upright to overturned, and therefore the exploratory drilling needs to be constantly adapted to its structural position. It should be emphasized, in particular, that the success of these studies depends on the geological mapping of the contact surface or underground mining works (Hajsek, 2005; Galić et. al., 2006-1, 2006-2, 2008).

Underground mining study works should be planned to be carried out at the contact surface itself and to be used as exploitation objects after a deposit is found. After a geologist determines the position of the contact surface in relation to underground mining research, the design of exploratory drilling is being approached. It is necessary to carry out drilling with core drilling.

This approach resulted in finding new bauxite deposits from underground mining works and completing the survey of foundations that were only partially detected by drilling from the surface. (Dragičević et al., 2007; Galić et al., 2006, 2008).

\subsection{Methods of exploratory drilling from underground mining sites}

\section{a) Drilling down}

The explorative drilling down will occur when the contact surface is inclined and vertical or approximately vertical. Then the upper corridor (780) will be punched down (690) and the contact surface will be monitored as shown in Figures 3a and $\mathbf{3 b}$.

\section{b) Drilling down and up}

The exploration drill downwards and upwards will be applied when the contact surface changes the posting and tilting position frequently and appears in the overturned position. If the exploration corridor moves away from the contact surface then it is necessary to create access to the contact surface, and then the study mode described above (see Figure 4) applies.

\section{c) Drilling upwards}

Drilling up is used only in special cases, for example when there is an inaccessible terrain and it is impossible to drill from the surface, or the deposit is closer to underground mining facilities than the surface, or to prevent property-legal relations. In these cases, we have the opportunity to drill the existing underground mining facilities to the surface as shown in Figure 5.

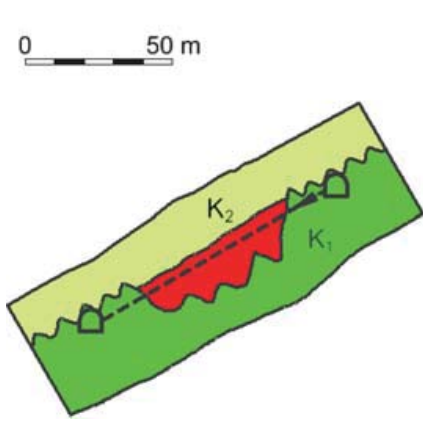

a) inclined surface

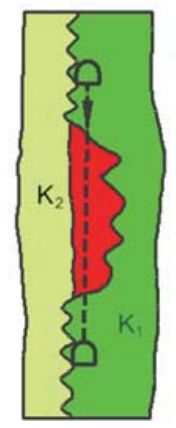

b) vertical surface

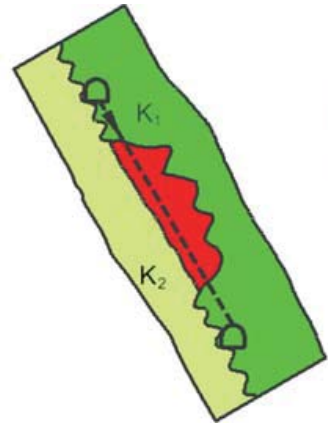

c) overturned surface

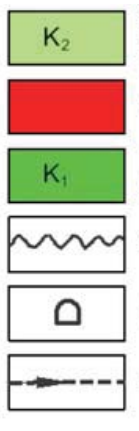

carbonate clastics: breccias, conglomerates, calcarenite and calcareous marl (Upper Cretaceous:Santonian-Campanian) bauxite (bx)

limestone and dolomite (Lower Cretaceous: Barremian-Albian) tectonic-erosional discordance investigation hall trace drilling the borehole with the direction

Figure 3: Schematic illustration of drilling model from top to bottom (Budeš, 2009)

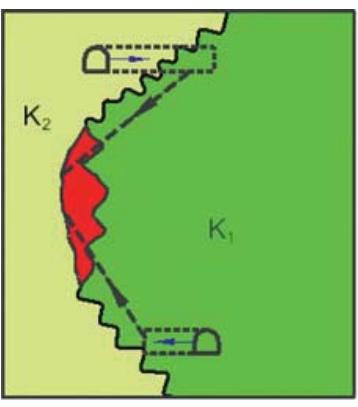

a) the position of the bauxite deposit in the crest of the subsided anticline
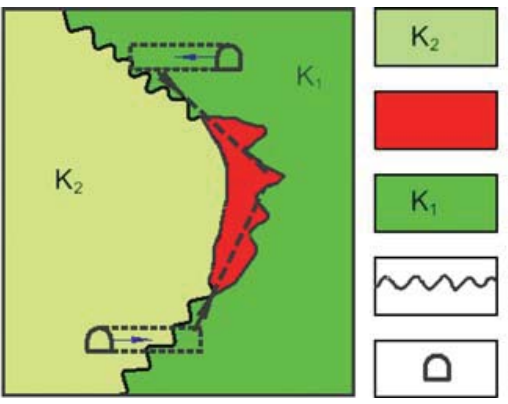

Upper Cretaceous

bauxite (bx)

Lower Cretaceous

tectonic-erosional discordance

investigation hall

b) the position of the bauxite

deposit at the core

of the subsided anticline

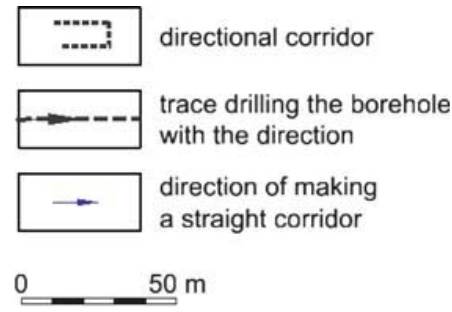

Figure 4: Schematic illustration of drilling model when the investigative corridor is away from the contact surface either in the underlying or overlying rocks (Budeš, 2009) 


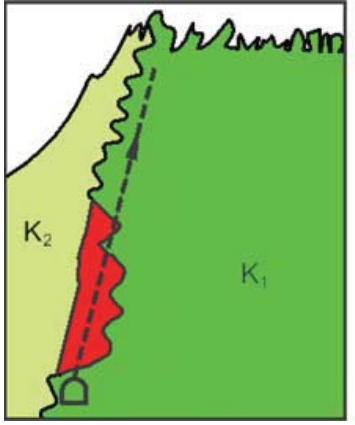

a) sub vertical surface

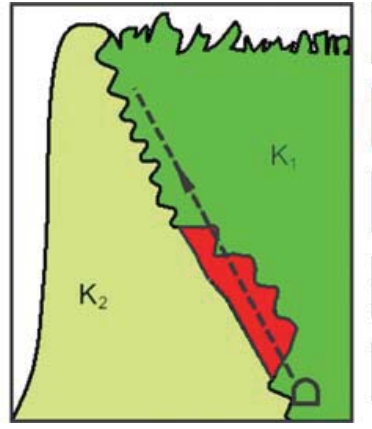

b) overturned surface

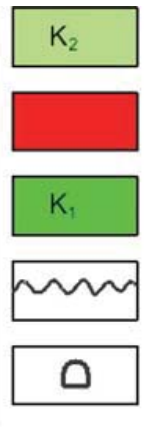

Upper Cretaceous

bauxite (bx)

Lower Cretaceous

tectonic-erosional

discordance

investigation hall

Figure 5: Schematic illustration of the drilling model bottom-up (Budeš, 20og)

\subsection{Examples of application of a new approach to the bauxite deposit study}

Up until now, in the area of Bešpelj, studies were done exclusively by drilling from the surface. Further drilling from the surface would be extremely irrational, because the cost of research would raise the price of bauxite up to $50 \%$. If the costs of exploitation were still taken into account, the final result would be disadvantageous and ineffective. Therefore, a new approach to the study of the bauxite deposit has been applied, and research has continued with the construction of subterranean and underground corridors which will also open the mine. For the purpose of research and later the opening of the mine, corridors will be created to undermine the levels of 600,690 and $780 \mathrm{~m}$. The corridors come to the contact surface and then the investigative corridors follow the same route. The corridors can be run either in the foot wall or in the hanging wall but as close as possible to the contact surface. Later, during the exploitation phase, investigatory corridors will have the role of preparatory corridors, transport corridors and ventilation. Keeping all this in mind, the size and shape of the corridor is adapted to modern mechanization. From the room, investigative drilling would be made every 40 meters, and exploratory drilling would be created in places only where it would be needed (see Figure 6). The size of the research chamber is very important because it is necessary to mount the exploratory drill sets. However, research can be further rationalized if an integral study approach to the entire area is assumed that simultaneously explores the possibility of the existence of other mineral raw materials with bauxite deposits, such as dimension stone (Galić et al., 2015).

\section{Example L-29 deposits}

Bauxite Jajce mines have continued bauxite research in the area of Bešpelj and new deposits have been found and contoured in the last ten years. Studies are conducted by combined methods, underground rooms and exploratory drilling from the corridors that are directly adjacent to the contact surface. By constructing the 780 base and the investigative rooms located at the same level, the deposit L-29 (see Figure 7) was found. This deposit was completely in the study room, along the

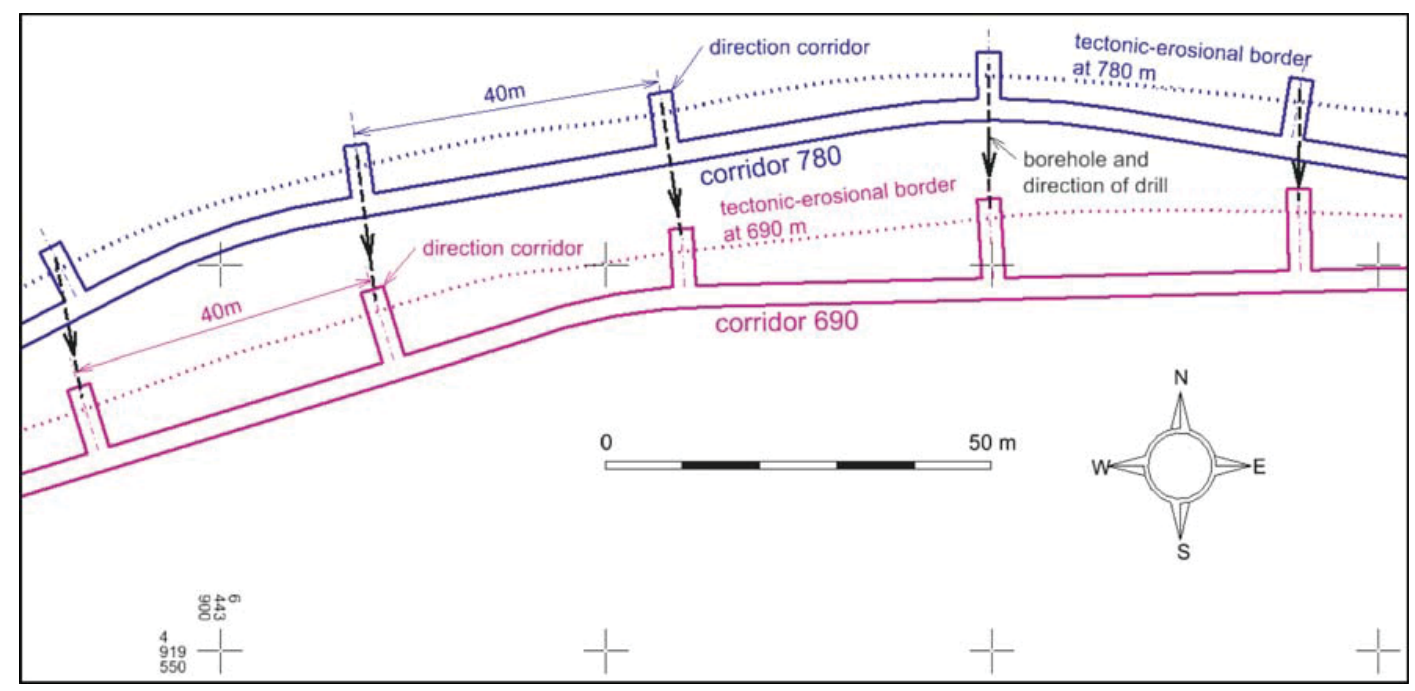

Figure 6: Schematic of study and directional corridors (Galić et al., 2006) 


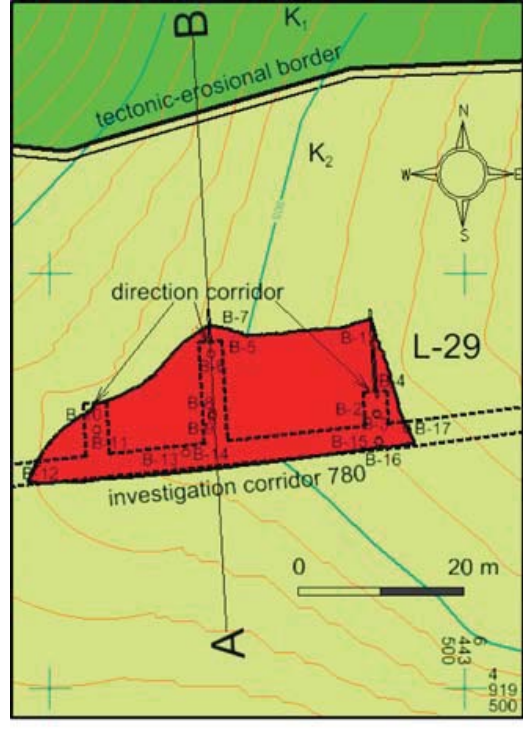

a) geological map

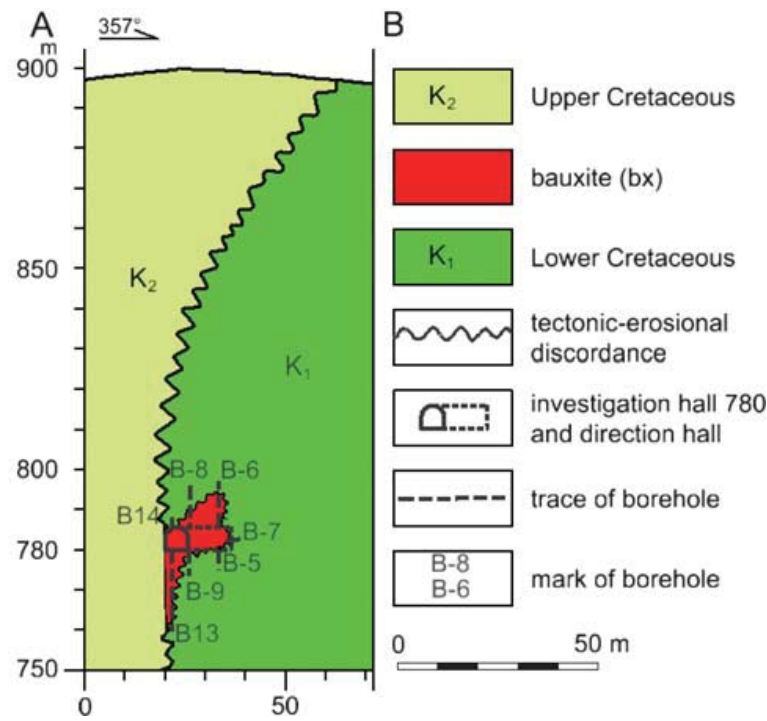

b) geological profile

Figure 7: Example drilling pattern on bauxite deposit L-29 (Dragičević et al., 2007; Galić et. al., 20o8)

contact surface, with three corridors perpendicular to the study room and 17 investigative boreholes made of longitudinal and directional corridors up and down from the level of the corridor 780 .

\section{Expected results}

\subsection{Model of research bauxite deposits from the surface}

The basic assumption in this analysis is that prior to the commencement of the investigation we have not yet determined the existence of any deposits. The aim is to determine the existence of bauxite deposits in the field of research and the theoretical value of total costs by a certain research method. Comparing research costs will result in the effectiveness of the research method.

In order to determine the effectiveness of investigations, either from the surface or from underground mining, it is necessary to determine or dimension the area of research (Haldar, 2013). The research area, hypothetically, must be identical to drilling from the surface and exploration works from the underground. Since the bauxite-bearing area Bešpelj is over $5 \mathrm{~km}$ long, an area 2,000 $\mathrm{m}$ long and $40 \mathrm{~m}$ wide is an example taken for analysis. If a proper network of investigative boreholes $40 \times 40 \mathrm{~m}$ is set, a total of 100 investigative boreholes will be obtained, which need to be drilled from the surface.

In addition to the dimensioning of the research area, it is also necessary to determine the depths (levels) at which investigations will be carried out both from the surface and in the underground. For this analysis, it was determined that the drilling depths are: 90, 180, 270 and $360 \mathrm{~m}$. Drilling depths are appropriate to the altitude where the main corridors will be.
The drilling price on the core, from the surface, amounts to an average of $100 € / \mathrm{m}$, up to $200 \mathrm{~m}$ in depth. The drilling price, from the surface, increases with depth at $25 € / 1$ loom. Surface research should also make an access road to the drilling site. The cost of developing access roads is $100 € / \mathrm{m}$.

\subsection{Model of research bauxite deposits \\ from underground mining facilities}

The study from underground mining works will be made from the corridors which will be at levels 780 , 690,600 and $510 \mathrm{~m}$. The length of the longitudinal investigative corridors will depend on the level at which they will be punched and will be:

$-2600 \mathrm{~m}$ for corridor 780

- $4100 \mathrm{~m}$ for corridor 690 .

$-6200 \mathrm{~m}$ for corridor 600

- $8300 \mathrm{~m}$ for corridor 510 .

The price of one meter of corridor is $400 €$. Investigative boreholes are planned every 40 meters along the corridor, as well as for surface drilling but only in one row, directly in the contact surface. There is no need for drilling in a second row because knowledge of structural and stratigraphic relations with the contact surface will be able to determine whether there is a bauxite deposit at that position. The drilling length is approximately 96 meters between the two main corridors because the slope of the contact surfaces of about $70^{\circ}$ and about $96 \mathrm{~m}$ from the surface 780 . This will effectively study the contact surface from level 510 to the surface area ( $870 \mathrm{~m}$ above sea level) and determine if there is a bauxite deposit in the area.

Accordingly, drilling will be performed on 50 locations in the length of a total of 360 meters. The drilling price on the core from underground mining works is $40 € / \mathrm{m}$. 
Table 1: Dependency of cost of site and depth of research

\begin{tabular}{|c|c|c|c|c|c|c|c|c|c|c|c|c|c|c|}
\hline \multirow{3}{*}{$\begin{array}{l}\text { Depth } \\
\text { m' }\end{array}$} & \multicolumn{7}{|c|}{ Investigations from the surface } & \multicolumn{7}{|c|}{ Investigations from underground rooms } \\
\hline & \multicolumn{3}{|c|}{ investigation drilling } & \multicolumn{3}{|c|}{ access road } & \multirow{2}{*}{$\begin{array}{c}\text { Total } \\
€\end{array}$} & \multicolumn{3}{|c|}{ investigation drilling } & \multicolumn{3}{|c|}{ underground rooms } & \multirow{2}{*}{$\begin{array}{c}\text { Total } \\
€\end{array}$} \\
\hline & $\begin{array}{c}\text { length } \\
\text { m' }\end{array}$ & $\begin{array}{l}\text { price } \\
€ / \mathrm{m},\end{array}$ & $\operatorname{cost} €$ & $\begin{array}{l}\text { length } \\
\text { m' }\end{array}$ & $\begin{array}{l}\text { price } \\
€ / \mathrm{m}^{\prime}\end{array}$ & $\operatorname{cost} €$ & & $\begin{array}{c}\text { length } \\
\text { m' }\end{array}$ & $\begin{array}{l}\text { price } \\
€ / \mathrm{m} \text { ' }\end{array}$ & $\operatorname{cost} €$ & $\begin{array}{c}\text { length } \\
\text { m' }\end{array}$ & $\begin{array}{l}\text { price } \\
€ / \mathrm{m} ’\end{array}$ & $\operatorname{cost} €$ & \\
\hline 90 & 9000 & 100 & 900000 & 2500 & 100 & $3 \mathrm{E}+05$ & 1150000 & 4790 & 40 & 191595 & 2600 & 400 & 1040000 & 1231595 \\
\hline 180 & 18000 & 100 & $2 \mathrm{E}+06$ & 2500 & 100 & $3 \mathrm{E}+05$ & 2050000 & 9580 & 40 & 383190 & 4100 & 400 & 1640000 & 2023190 \\
\hline 270 & 27000 & 125 & $3 \mathrm{E}+06$ & 2500 & 100 & $3 \mathrm{E}+05$ & 3625000 & 14370 & 40 & 574786 & 6200 & 400 & 2480000 & 3054786 \\
\hline 360 & 36000 & 150 & $5 E+06$ & 2500 & 100 & $3 \mathrm{E}+05$ & 5650000 & 19160 & 40 & 766381 & 8300 & 400 & 3320000 & 4086381 \\
\hline
\end{tabular}

However, there are additional costs involved in drilling chambers in the underground room study. Since the drilling chambers will not be made at each drilling position, but only in the required places where the corridors are to move away from the contact surface. It is assumed that, in the most unfavourable case, it will be necessary to make 40 chambers on four corridors $(780,690,600$ and 510).

The size of the chamber must be large enough to have a drill set in them. For the production of 20 chambers with a length of 5 meters on average, it is necessary to create 100 meters of corridor. The price of a corridor is $400 € / \mathrm{m}$.

\subsection{Results of the bauxite deposits research model analysis}

Based on the input data described in the research models, cost analysis was performed. The results of the analysis are shown in Table $\mathbf{1 .}$

The total exploration costs of the assumed area from underground mining facilities, up to a depth of $180 \mathrm{~m}$, are slightly higher than the cost of study from the surface. However, with a $190 \mathrm{~m}$ depth increase, surface exploration costs exceed the costs of exploration in underground mining facilities.

With the increase in the depth of the deposit or the length of the investigative boreholes, over 200 m' unit drilling price increases as the diameter of the introductory column increases. Therefore, with an increase in depth, the amount of exploration cost from the surface increases considerably compared to the study of underground rooms, as shown in Table 1 and Figure 8.

However, exploratory drilling from the surface does not follow the tilt of the contact surface and is therefore much more unreliable than underground research. In the underground study, opening and processing facilities are also preparation for the exploitation of the deposit and thus represent a large savings in total costs.

It can be established that after a certain depth of the study it is more cost-effective to create underground rooms than make drilling boreholes from the surface. It can be established that, after a certain depth of the study, it is more profitable to create underground rooms than drill boreholes from the surface.

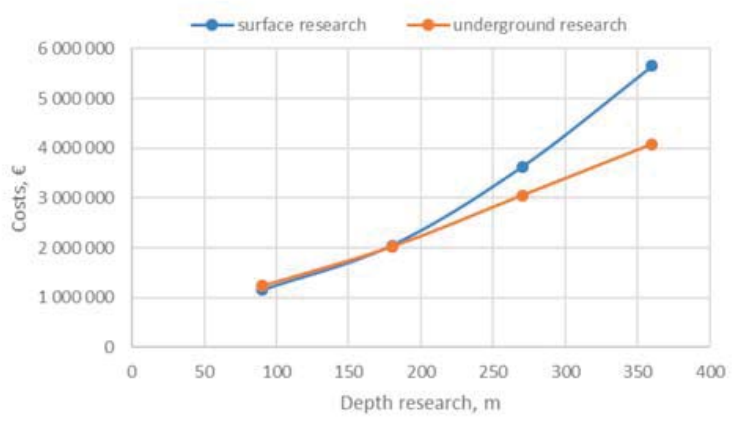

Figure 8: Diagram of the cost of surface and underground exploration

\section{Conclusion}

The Bešpelj exploitation field has been exploiting bauxite for many years now, but studies conducted so far have shown that there are still more valuable bauxite deposits in this area.

For a long time, detailed studies have been done by drilling from the surface. Due to complicated structural geological relations, inclined to vertical and overturned positions of the bauxite deposits, it was necessary to devise a new approach to the research of deposits. Investigative drilling from the surface to deep bauxite deposits is expensive and irrational. Therefore, a new approach to the study involving underground mining rooms and exploratory drilling from these rooms was proposed. The contact surface of the underlying and overlying rocks of the bauxite deposits is a steep but variable slope by providing and tilting. Therefore, with the creation of underground mining rooms, geological mapping has to be carried out with the aim of further routing works.

In this paper, the presented concept of research by making investigative boreholes from longitudinal corridors directly to the contact surface gives great probability of finding new bauxite deposits.

Analysing the economic indicators, it was found that the cost of underground mining study was nominally lower than the surface study drilling because part of the cost is the preparation for the exploitation of bauxite. The proposed approach can be used to determine the 
boundary depth of the study under which much more favorable research from underground mining works, even if the underground rooms are designed as intended for exploration drilling rooms.

\section{References}

Bárdossy, G. (2013): Karst bauxites: Developments in Economic Geology 14. Elsevier, Amsterdam, 442 p.

Budeš, I. (2009): Exploration of bauxite from underground mining, graduate thesis, 27 p. Faculty of Mining, Geology and Petroleum Engineering, Zagreb.

Crnoja, F. (2015): Geological settings in the bauxite bearing area „Poljane“ near Jajce (BiH) with special emphasis on deposits of bauxite and dimension stone : master's thesis, 26 p. Faculty of Mining, Geology and Petroleum Engineering, Zagreb.

Dragičević, I. (1981): Geological settings in the bauxite-baering area Jajce (in Croatian), Master's thesis. Faculty of Mining, Geology and Petroleum Engineering, University of Zagreb, p. 65, Zagreb.

Dragičević, I. (1987): Palaeogeographic evolution of the edge of the Mesozoic carbonate platform of Dinarides between the Vrbas and Bosnia (in Croatian). PhD Thesis, Faculty of Mining, Geology and Petroleum Engineering, University of Zagreb, p. 90, Zagreb.

Dragičević, I. \& Velić, I. (1994): Stratigraphical position and significance of reef facies at the Northern margin of the Dinaric carbonate platform during the Late Jurassic and Cretaceous in Croatia and Bosnia. Geologie Mediterranee, Tome XXI, NO 3-4, pp.59-63, Marseille.

Dragičević, I. (1997): The Bauxites of the Northern Margin of the Dinarides Carbonate Platform (Area of Jajce, Bosnia). 8th Internat. Congress of ICSOBA, Milan, April 16/181997, Travaux, ICSOBA, 24, 64-73, Milan.

Dragičević, I., Nuić, J., Nuić, M. (2003): Study on Classification, Categorization and Budget of Red Bauxite Reserves on deposits: L-20, L-24, L-25, L-26, L-27, L-34 and L-35 in the area of Bešpelj (Jajce-B\&H), Faculty of Mining, Geology and Petroleum Engineering, Zagreb.

Dragičević, I,. Velić., I (2006): Litostratigraphic settings of bauxite deposits in the Bešpelj Area (in Croatian). GEOECO.ing d.o.o. p.30, Zagreb

Dragičević, I., Galić, I. (2007): Study on Classification, Categorization and Budget of Red Bauxite Reserves on L-29 in the area of Bešpelj (Jajce-B\&H), Faculty of Mining, Geology and Petroleum Engineering, Zagreb.
Farkaš, B. (2006): Modeling of the bauxite area Vlasinje with the concept of new research works, graduate thesis, $62 \mathrm{p}$. Faculty of Mining, Geology and Petroleum Engineering, Zagreb.

Galić, I., Krasić, D. \& Dragičević, I. (2015): Evaluation of research in a bauxite-bearing area on a locality „Crvene stijene" with emphasis on exploitation of associated deposits. Geologia Croatica, 68, 3, 225-236.

Galić, I., Dragičević, I., Živković, SA, Janković, B., Hajsek, D., Radovac, T., Kovacsics, A., Jószef, H., Podanyi, T. (2006): Main Mining Project exploitation of bauxite deposits in the exploitation field "Bešpelj", Faculty of Mining, Geology and Petroleum Engineering, Zagreb.

Galić, I., Dragičević, I., Radovac, T. (2006): Appliance of computer programs in modeling of surface and underground pits. International Mining Symposium-Mining 2006. Exploration, exploitation and processing of solid mineral raw materials, Žunec, Nenad ; Horvat, Jasna ; Bunić, Silvija (ed.). Grafika Hrašće, 126-139, Zagreb.

Galić, I., Dragičević, I., Janković, B., Hajsek, D., Radovac, T., Kovacsics, A., Podanyi, T. (2008): Addition Mining Project exploitation of bauxite deposits in the exploitation field "Bešpelj" (L-29), Faculty of Mining, Geology and Petroleum Engineering, Zagreb.

Hajsek, D. (2005): The use of computer programs in the process of forming opening, elaborating and exploring rooms in exsploatation field "Bešpelj", graduate thesis, 27 p. Faculty of Mining, Geology and Petroleum Engineering, Zagreb.

Haldar, S.K. (2013): Mineral Exploration: Principles and Applications. Elsevier, Amsterdam, 334 p.

Ilić, Z. (1989): Conceptual solution for exploration and opening of reservoir Bešpelj in bauxite Jajce mine, Zemun Mining Institute.

Marinković, R. and Ahac, A. (1975): Basic geological map 1:100 000, Jajce sheet. Geo Engineering, Institute of Geology, Sarajevo.

Papeš, J. (1984): Geological map of the bauxite fields of Liskovica, Bešpelj, Seoca, Crvene Stijene and Poljane, at Jajce, M1: 25000. Geo Engineering, Institute of Geology, Sarajevo.

Slanc, G. (2011): Impact of the inclination of the bauxite contact surface and supporting rocks on the type and layout of investigative works in the area of Bešpelj, final work-baccalareus, Faculty of Mining, Geology and Petroleum Engineering, 41 p., Zagreb.

\section{Author's contribution}

Ivan Budeš (technical manager) - the main contribution is to create a model of underground mining works to investigate bauxite deposits. Ivo Galić (Associate Professor) - the main contribution is in conjunction with the development of new approaches and models of research bauxite from underground mining operations and comparative analysis of the efficiency of research from the surface and from underground chambers. Ivan Dragičević (Retired Professor) - the main contribution is in defining geological relations in the field of research and collaboration in the development of a new approach and model of research of bauxite deposits from underground mining works. 